\title{
Optimization of the Preparation of Fish Protein Anti-Obesity Hydrolysates Using Response Surface Methodology
}

\author{
Liyuan Liu ${ }^{1,2}$, Yanping Wang ${ }^{1, *}$, Chen Peng ${ }^{1}$ and Jinju Wang ${ }^{1}$
}

1 Key Laboratory of Food Nutrition and Safety, Ministry of Education, Tianjin University of Science \& Technology, Tianjin 300457, China; E-Mails: liuliyuan0206@163.com (L.L.); pengchen1211@mail.tust.cn (C.P.); bioorange@163.com (J.W.)

2 Ocean College of Hebei Agricultural University, Qinhuangdao 066000, China

* Author to whom correspondence should be addressed; E-Mail: ypwang40@yahoo.com; Tel.: +86-133-156-952-88; Fax: +86-22-6060-1457.

Received: 18 October 2012; in revised form: 13 November 2012 / Accepted: 15 November 2012 / Published: 1 February 2013

\begin{abstract}
The enzymatic condition for producing the anti-obesity hydrolysates from fish water-soluble protein was optimized with the aid of response surface methodology, which also derived a statistical model for experimental validation. Compared with neutral protease, papain and protamex, the porcine pancreas lipase inhibitory rate of hydrolysates from fish water-soluble protein was higher with alkaline protease. Results showed that the model terms were significant, the terms of lack of fit were not significant, and the optimal conditions for the hydrolysis by alkaline protease were initial $\mathrm{pH} 11$, temperature $39{ }^{\circ} \mathrm{C}$, enzyme dosage $122 \mathrm{U} / \mathrm{mL}$ and $10 \mathrm{~h}$ of hydrolysis time. Under these conditions, the porcine pancreas lipase and the $\alpha$-amylase inhibitory rate could reach $53.04 \% \pm 1.32 \%$ and $20.03 \pm 0.89 \%$, while predicted value were $54.63 \% \pm 1.75 \%, 21.22 \% \pm 0.70 \%$, respectively. In addition, Lineweaver-Burk plots showed noncompetitive inhibition. The $K_{\mathrm{i}}$ value calculated was $84.13 \mathrm{mg} / \mathrm{mL}$. These results demonstrated that fish water-soluble protein could be used for obtaining anti-obesity hydrolysates.
\end{abstract}

Keywords: anti-obesity; fish protein; kinetics; porcine pancreas lipase; $\alpha$-amylase; response surface methodology (RSM) 


\section{Introduction}

With the development of modern society, prevalence of obesity is seriously threatening global health owing to people's life style of decreased physical activity and intake of high energy food $[1,2]$. It is well-known that obesity is associated with many chronic diseases such as hyperlipidemia, hypertension, coronary heart disease, type II diabetes, cancers and other serious diseases [3]. Obesity is a disarray of energy balance and primarily considered as a disorder of lipid metabolism. A growing number of enzymes involved in lipid metabolic pathways are being identified and characterized. They represent a rich pool of potential therapeutic targets for obesity. In the course of the lipid metabolism, pancreatic lipase is the key enzyme for the digestion of triglycerides. Dietary triglycerides are hydrolyzed by pancreatic lipase to monoglycerides, free fatty acids and other small molecules, which are absorbed in the intestine and then resynthesize triglycerides for the person of food intake leading to obesity ultimately. So, the inhibition of lipase is efficient to prevent obesity, which is one of the most important methods for valuing anti-obesity activity in vitro [4]. Many drugs have been found to treat obesity, such as Orlistat, which is well known as a gastric and pancreatic lipase inhibitor [5]. Another important approach for controlling weight is to reduce or slow dietary carbohydrate digestion and absorption. Starch digestion primarily occurs through the action of $\alpha$-amylase, yielding both linear maltose and branched isomaltose oligosaccharides, which are further hydrolyzed by $\alpha$-glucosidases to release absorbable monosaccharide [6,7]. By inhibiting $\alpha$-amylase involved in carbohydrate digestion, it significantly delays postprandial hyperglycemia and hinders energy production [8]. Therefore, in this study, the inhibition of pancreatic lipase, assisted with $\alpha$-amylase inhibitory activity, was selected as the evaluation criterion of anti-obesity.

In several studies, it has been reported that the anti-obesity activities were shown by protamine [9], wheat proteins [10,11], soybean cotyledon proteins [12], defatted rice bran proteins and lupin proteins [13,14], as well as soybean hydrolysates [15], black soybean hydrolysates [16,17], bovine hemoglobin hydrolysates [18]. Only a few studies have reported the hypolipidemic, cholesterol-lowering [19], antihypertensive [20], antioxidant effects [21-24], immunomodulating [25,26] and antiproliferative activities of fish protein and hydrolysates. There have hitherto been no reports on the inhibitory effects of fish protein hydrolysates (FPH) on obesity. Enzymatic proteolysis applied to proteinaceous fish by-products has been described as a means to transform these materials into more marketable and value-added products with improved functional and biological properties.

Response surface methodology (RSM) is an effective tool for optimizing reaction parameters. Many bioactive peptides or hydrolysates have been optimized using RSM, including the angiotensin-converting enzyme inhibitors from whey protein and collagen, enzymatic hydrolysis of protein concentrates or waste protein by commercial proteases [27-30], and antioxidant hydrolysates from shrimp processing discards and saithe [31].

In this study, RSM was used to identify the most important variables for optimizing the enzymatic hydrolysis conditions, under which it was expected to obtain original and effective hydrolysates for anti-obesity, which might be an excellent alternative strategy for the development of safe and effective anti-obesity drugs. 


\section{Results and Discussion}

\subsection{Effects of Different Proteases Hydrolysis for Producing Anti-Obesity Hydrolysates}

Figure 1a shows the hydrolysis curves of each protease obtained at the optimal initial $\mathrm{pH}$ and temperature, with the substrate concentration of $0.22 \%(w / v)$ fish water-soluble protein and enzyme dosage $100 \mathrm{U} / \mathrm{mL}$. The degree of hydrolysis (DH) increased significantly when the hydrolysis time was prolonged from 0 to $8 \mathrm{~h}$, and peaked at $10 \mathrm{~h}$. When hydrolysis time was longer than $10 \mathrm{~h}, \mathrm{DH}$ started to maintain a dynamic equilibrium with a slight increase. These results indicated that four proteases showed certain catalytic activities. During the hydrolysis processing, the DH value of alkaline protease was significantly higher than that of other proteases.

Figure 1. Degree of hydrolysis (a) and porcine pancreas lipase (PPL) inhibitory rate (b) during different stages of enzymatic hydrolysis using four proteases. The error bars represent standard deviations from three independent samples.

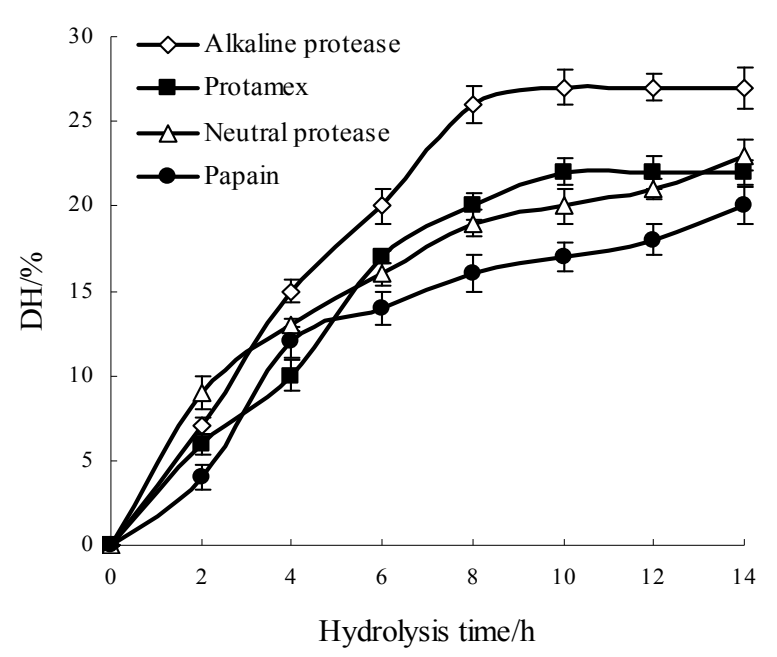

(a)

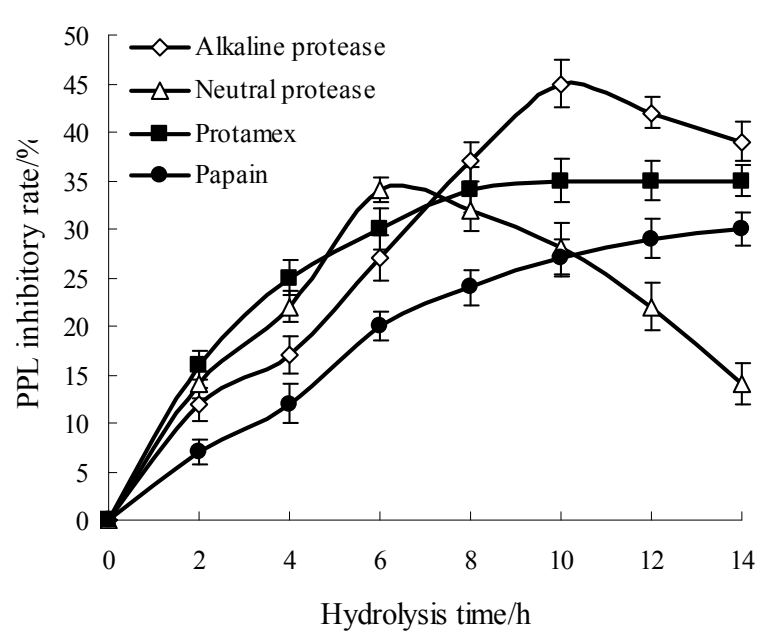

(b)

Suitable enzymes for marine protein hydrolysis should be selected according to various criteria, such as flavor extraction, physicochemical properties of the resulting hydrolysate, or reduction of bitterness by limiting the release of hydrophobic amino acids. From Figure 1b, a comparative study of four proteases was performed on PPL inhibitory activity of FPH. The highest PPL inhibitory rate was obtained using alkaline protease at the maximal point compared to neutral protease, protamex and papain. Alkaline protease has been chosen by many authors due to its efficiency to hydrolyze fish protein at laboratory scale [32,33]. Klompong et al. [23] have reported at low DH (5\%), protein hydrolysate of yellow stripe trevally (Selaroides leptolepis) with alkaline protease exhibited a better DPPH radical-scavenging activity compared to Flavourzyme. During the reaction process, the PPL inhibitory rate increased at the beginning, reached the maximal value, and then decreased rapidly, when the FPH were hydrolyzed by neutral protease. Similarly, the PPL inhibitory rate of FPH with alkaline protease increased with reaction time, and reached the maximal value at $10 \mathrm{~h}$, and then decreased slowly. This indicated that a hydrolysis time of $10 \mathrm{~h}$ was fit to obtain anti-obesity hydrolysates. A very long hydrolysis time might induce the degradation of polypeptide, which would 
lead to changes in the polypeptide molecular weight and a decrease in PPL inhibitory rate. Nevertheless, the structure-activity relationship and the anti-obesity mechanism of active peptides were not yet fully elucidated. The anti-obesity activity of hydrolysates has been related both to the enzyme specificity, the degree of hydrolysis, and the amino acid composition and sequence of the different peptides released. Therefore, it can be concluded that alkaline protease could be a suitable protease for catalytic hydrolysis of fish water-soluble protein, and $10 \mathrm{~h}$ was selected as the center point of the hydrolysis time in the RSM experiment.

\subsection{Fitting the Model}

RSM was used to develop a predicted model for optimizing the PPL and $\alpha$-amylase inhibitory activities of FPH. The experimental conditions and the corresponding values from the experimental design were presented in Table 1. All tests were performed in triplicate. Values represented the mean \pm standard deviations.

Table 1. Box-Behnken design and responses.

\begin{tabular}{|c|c|c|c|c|c|c|}
\hline \multirow[b]{2}{*}{ RUN } & \multicolumn{4}{|c|}{ Independent variables } & \multirow{2}{*}{$\begin{array}{c}\text { Response }\left(\mathrm{Y}_{1}\right) \\
\text { PPL inhibitory } \\
\text { rate }(\%)\end{array}$} & \multirow{2}{*}{$\begin{array}{c}\text { Response }\left(\mathrm{Y}_{2}\right) \\
\alpha \text {-amylase } \\
\text { inhibitory rate }(\%)\end{array}$} \\
\hline & $\begin{array}{r}\text { Initial } \\
\text { pH }\left(\chi_{1}\right) \\
\end{array}$ & $\begin{array}{c}\text { Temperature } \\
\left(\chi_{2}\right),{ }^{\circ} \mathrm{C} \\
\end{array}$ & $\begin{array}{c}\text { Enzyme dosage } \\
\left(\chi_{3}\right), \mathbf{U} / \mathbf{m L}\end{array}$ & $\begin{array}{l}\text { Hydrolysis } \\
\text { time }\left(\chi_{4}\right), \mathbf{h} \\
\end{array}$ & & \\
\hline 1 & 0 & -1 & 1 & 0 & $47.19 \pm 1.24$ & $19.44 \pm 0.82$ \\
\hline $2^{a}$ & 0 & 0 & 0 & 0 & $53.54 \pm 1.15$ & $20.58 \pm 0.69$ \\
\hline 3 & 0 & 0 & 1 & 1 & $39.39 \pm 0.53$ & $18.22 \pm 0.77$ \\
\hline 4 & 1 & -1 & 0 & 0 & $40.71 \pm 1.01$ & $17.92 \pm 1.04$ \\
\hline 5 & 1 & 1 & 0 & 0 & $27.58 \pm 0.93$ & $18.04 \pm 1.12$ \\
\hline $6^{\mathrm{a}}$ & 0 & 0 & 0 & 0 & $53.07 \pm 1.52$ & $19.24 \pm 0.62$ \\
\hline 7 & 1 & 0 & 0 & -1 & $27.56 \pm 1.33$ & $16.61 \pm 0.45$ \\
\hline 8 & -1 & 0 & 0 & 1 & $37.54 \pm 1.49$ & $16.92 \pm 0.51$ \\
\hline 9 & -1 & -1 & 0 & 0 & $43.19 \pm 0.58$ & $13.45 \pm 0.44$ \\
\hline 10 & 1 & 0 & -1 & 0 & $29.27 \pm 1.02$ & $16.08 \pm 0.73$ \\
\hline 11 & 0 & 1 & -1 & 0 & $27.32 \pm 0.75$ & $15.36 \pm 0.77$ \\
\hline 12 & 0 & 0 & -1 & -1 & $25.63 \pm 1.65$ & $11.36 \pm 0.36$ \\
\hline 13 & 0 & 1 & 1 & 0 & $40.45 \pm 0.87$ & $18.96 \pm 0.32$ \\
\hline $14^{\mathrm{a}}$ & 0 & 0 & 0 & 0 & $54.15 \pm 1.07$ & $20.19 \pm 0.54$ \\
\hline 15 & 1 & 0 & 1 & 0 & $42.50 \pm 1.44$ & $20.17 \pm 0.62$ \\
\hline 16 & -1 & 1 & 0 & 0 & $35.48 \pm 0.95$ & $18.37 \pm 0.65$ \\
\hline 17 & 0 & -1 & -1 & 0 & $39.32 \pm 1.27$ & $14.27 \pm 0.49$ \\
\hline 18 & 1 & 0 & 0 & 1 & $37.47 \pm 0.82$ & $17.88 \pm 0.61$ \\
\hline 19 & 0 & 1 & 0 & -1 & $31.44 \pm 0.98$ & $16.02 \pm 0.32$ \\
\hline 20 & -1 & 0 & 0 & -1 & $34.52 \pm 1.02$ & $11.73 \pm 0.47$ \\
\hline 21 & -1 & 0 & -1 & 0 & $41.61 \pm 1.31$ & $13.98 \pm 0.56$ \\
\hline 22 & 0 & 0 & -1 & 1 & $37.36 \pm 0.64$ & $14.29 \pm 0.55$ \\
\hline 23 & 0 & 1 & 0 & 1 & $30.39 \pm 1.16$ & $15.63 \pm 0.69$ \\
\hline 24 & 0 & -1 & 0 & -1 & $32.56 \pm 1.09$ & $12.08 \pm 0.44$ \\
\hline $25^{\mathrm{a}}$ & 0 & 0 & 0 & 0 & $54.16 \pm 0.85$ & $20.83 \pm 0.39$ \\
\hline
\end{tabular}


Table 1. Cont.

\begin{tabular}{|c|c|c|c|c|c|c|}
\hline \multirow[b]{2}{*}{ RUN } & \multicolumn{4}{|c|}{ Independent variables } & \multirow{2}{*}{$\begin{array}{c}\text { Response }\left(\mathrm{Y}_{1}\right) \\
\text { PPL inhibitory } \\
\text { rate }(\%) \\
\end{array}$} & \multirow{2}{*}{$\begin{array}{c}\text { Response }\left(\mathrm{Y}_{2}\right) \\
\alpha \text {-amylase } \\
\text { inhibitory rate }(\%)\end{array}$} \\
\hline & $\begin{array}{l}\text { Initial } \\
\text { pH }\left(\chi_{1}\right)\end{array}$ & $\begin{array}{c}\text { Temperatur } \\
\text { e }\left(\chi_{2}\right),{ }^{\circ} \mathrm{C}\end{array}$ & $\begin{array}{c}\text { Enzyme dosage } \\
\left(\chi_{3}\right), \mathbf{U} / \mathbf{m L}\end{array}$ & $\begin{array}{l}\text { Hydrolysis } \\
\text { time }\left(\chi_{4}\right), \mathrm{h}\end{array}$ & & \\
\hline 26 & 0 & 0 & 1 & -1 & $47.09 \pm 0.72$ & $17.03 \pm 0.52$ \\
\hline $27^{\mathrm{a}}$ & 0 & 0 & 0 & 0 & $52.01 \pm 0.64$ & $21.35 \pm 0.42$ \\
\hline 28 & 0 & -1 & 0 & 1 & $40.53 \pm 0.58$ & $16.85 \pm 0.31$ \\
\hline 29 & -1 & 0 & 1 & 0 & $46.82 \pm 0.62$ & $18.39 \pm 0.37$ \\
\hline
\end{tabular}

${ }^{\mathrm{a}}$ center point; PPL, porcine pancreas lipase.

Table 2 showed the ANOVA for the PPL and the $\alpha$-amylase inhibitory activities of FPH. It was found that the two statistical model were significant at a 99\% confidence level $(p<0.01)$, which meant there was only a $0.01 \%$ chance that a "model $F$-value" could occur due to noise. As the test of lack of fit hypothesis was not significant $(p>0.05)$ in model equations, the models were fitted to the PPL and the $\alpha$-amylase inhibitory rate data.

Table 2. Results of ANOVA for porcine pancreas lipase (PPL) inhibitory activity and $\alpha$-amylase inhibitory activity of fish protein hydrolysate (FPH).

\begin{tabular}{|c|c|c|c|c|c|c|c|c|}
\hline \multirow[b]{2}{*}{ Source } & \multicolumn{4}{|c|}{ The PPL inhibitory rate (\%) } & \multicolumn{4}{|c|}{ The $\alpha$-amylase inhibitory rate $(\%)$} \\
\hline & $\begin{array}{l}\text { Sum of } \\
\text { squares }\end{array}$ & $\begin{array}{c}\text { Mean } \\
\text { square }\end{array}$ & $F$-value & $p$-value & $\begin{array}{c}\text { Sum of } \\
\text { squares }\end{array}$ & $\begin{array}{c}\text { Mean } \\
\text { square }\end{array}$ & $F$-value & $p$-value \\
\hline Model & 2104.13 & 150.29 & 48.88 & $<0.0001 * *$ & 209.26 & 14.95 & 30.14 & $<0.0001 * *$ \\
\hline$\chi_{1}$ & 96.73 & 96.73 & 31.46 & $<0.0001 * *$ & 16.01 & 16.01 & 32.28 & $<0.0001 * *$ \\
\hline$\chi_{2}$ & 215.39 & 215.39 & 70.05 & $<0.0001 * *$ & 5.84 & 5.84 & 11.77 & $0.0041 * *$ \\
\hline$\chi_{3}$ & 330.02 & 330.02 & 107.33 & $<0.0001 * *$ & 60.17 & 60.17 & 121.34 & $<0.0001 * *$ \\
\hline$\chi_{4}$ & 47.52 & 47.52 & 15.46 & $0.0015 * *$ & 18.65 & 18.65 & 37.61 & $<0.0001 * *$ \\
\hline$\chi_{1} \chi_{2}$ & 7.34 & 7.34 & 2.39 & $0.1445 \mathrm{~ns}$ & 5.76 & 5.76 & 11.62 & $0.0042 * *$ \\
\hline$\chi_{1} \chi_{3}$ & 16.08 & 16.08 & 5.23 & $0.0383 *$ & 0.026 & 0.026 & 0.052 & $0.8235 \mathrm{~ns}$ \\
\hline$\chi_{1} \chi_{4}$ & 11.87 & 11.87 & 3.86 & $0.0696 \mathrm{~ns}$ & 3.84 & 3.84 & 7.75 & $0.0147 *$ \\
\hline$\chi_{2} \chi_{3}$ & 6.92 & 6.92 & 2.25 & $0.1559 \mathrm{~ns}$ & 0.62 & 0.62 & 1.24 & $0.2837 \mathrm{~ns}$ \\
\hline$\chi_{2} \chi_{4}$ & 20.34 & 20.34 & 6.62 & $0.0222 *$ & 6.66 & 6.66 & 13.42 & $0.0026 * *$ \\
\hline$\chi_{3} \chi_{4}$ & 94.38 & 94.38 & 30.70 & $<0.0001 * *$ & 0.76 & 0.76 & 1.53 & $0.2370 \mathrm{~ns}$ \\
\hline$\chi_{1}^{2}$ & 409.97 & 409.97 & 133.33 & $<0.0001 * *$ & 14.34 & 14.34 & 28.92 & $<0.0001 * *$ \\
\hline$\chi_{2}^{2}$ & 520.90 & 520.90 & 169.41 & $<0.0001 * *$ & 22.94 & 22.94 & 46.27 & $<0.0001 * *$ \\
\hline$\chi_{3}^{2}$ & 195.33 & 195.33 & 63.53 & $<0.0001 * *$ & 19.54 & 19.54 & 39.41 & $<0.0001 * *$ \\
\hline$\chi_{4}^{2}$ & 756.07 & 756.07 & 245.90 & $<0.0001 * *$ & 72.88 & 72.88 & 146.98 & $<0.0001 * *$ \\
\hline Residual & 43.05 & 3.07 & - & - & 6.94 & 0.50 & - & - \\
\hline Lack of fit & 39.85 & 3.98 & 4.98 & $0.0678 \mathrm{~ns}$ & 4.44 & 0.44 & 0.71 & $0.7002 \mathrm{~ns}$ \\
\hline Pure error & 3.20 & 0.80 & - & - & 2.50 & 0.63 & - & - \\
\hline Total & 2147.17 & - & - & - & 216.20 & - & - & - \\
\hline \multicolumn{5}{|c|}{$R^{2}=0.9800, \operatorname{Adj} R^{2}=0.9599, \operatorname{Pre} R^{2}=0.8908$} & \multicolumn{4}{|c|}{$R^{2}=0.9679, \operatorname{Adj} R^{2}=0.9358$, Pre $R^{2}=0.8636$} \\
\hline
\end{tabular}

Values of $p<0.05$ indicated that the model terms were significant and the models had some power to explain the variation in the responses. In this case, for the PPL inhibitory activity, $\chi_{1}, \chi_{2}, \chi_{3}, \chi_{4}, \chi_{1} \chi_{3}$, 
$\chi_{2} \chi_{4}, \chi_{3} \chi_{4}$ were significant model terms. The higher the $\mathrm{F}$ value, the more important was the role in the hydrolysis process; therefore, enzyme dosage $\left(\chi_{3}\right)$ played a dominant role in the process. Ren et al. [34] have reported that $[\mathrm{E}] /[\mathrm{S}]$ exerted the significant effect on antioxidant activity of the hydrolysates derived from grass carp sarcoplasmic protein. Zhuang et al. [35] have also found [E]/[S] exhibited the highest significant effect on hydroxyl radical scavenging activity of jellyfish umbrella collagen hydrolysates. Furthermore, the interactive terms $\left(\chi_{3} \chi_{4}\right)$ presented a significant effect on the PPL inhibitory rate, namely, the interactions between enzyme dosage and hydrolysis time.

For the PPL inhibitory activity, the high coefficient of determination value $\left(R^{2}=0.9800\right)$ indicated that $98.00 \%$ of the variability in the response could be explained by the model. The adjusted $R^{2}$ value and predicted $R^{2}$ value for responses were 0.9599 and 0.8908 respectively, which also presented a model of a good fit. Therefore, the proposed models were adequate for presenting the real relationship among the parameters chosen.

The best explanatory model equations for the PPL inhibitory rate $\left(\mathrm{Y}_{1}\right)$ and the $\alpha$-amylase inhibitory rate $\left(\mathrm{Y}_{2}\right)$ of FPH were as follows:

$$
\begin{aligned}
\mathrm{Y}_{1}= & 53.39-2.84 \chi_{1}-4.24 \chi_{2}+5.24 \chi_{3}+1.99 \chi_{4}-1.35 \chi_{1} \chi_{2}+2.00 \chi_{1} \chi_{3}+1.72 \chi_{1} \chi_{4}+ \\
& 1.32 \chi_{2} \chi_{3}-2.25 \chi_{2} \chi_{4}-4.86 \chi_{3} \chi_{4}-7.95 \chi_{1}^{2}-8.96 \chi_{2}^{2}-5.49 \chi_{3}^{2}-10.80 \chi_{4}^{2} \\
\mathrm{Y}_{2}= & 20.44+1.16 \chi_{1}+0.70 \chi_{2}+2.24 \chi_{3}+1.25 \chi_{4}-1.20 \chi_{1} \chi_{2}-0.080 \chi_{1} \chi_{3}-0.98 \chi_{1} \chi_{4}- \\
& 0.39 \chi_{2} \chi_{3}-1.29 \chi_{2} \chi_{4}-0.44 \chi_{3} \chi_{4}-1.49 \chi_{1}^{2}-1.88 \chi_{2}^{2}-1.74 \chi_{3}^{2}-3.35 \chi_{4}^{2}
\end{aligned}
$$

\subsection{Analysis of Response Surfaces}

Three dimensional plots of the responses based on Equations 1 and 2 were presented in Figures 2 and 3 respectively, where two variables were kept at central point levels and the other two were allowed to vary within the experimental range.

As can be seen from Figure 2a, at a fixed temperature, the PPL inhibitory rate increased at the beginning and then decreased with increase of initial $\mathrm{pH}$ value. When the hydrolysis temperature was increased from 35 to $40{ }^{\circ} \mathrm{C}$, there was an increasing trend in the PPL inhibitory rate of FPH, and the maximum inhibitory rate was observed at about $40{ }^{\circ} \mathrm{C}$. The inhibitory rate decreased gradually, when the hydrolysis temperature was higher than $40{ }^{\circ} \mathrm{C}$. The report by Hou et al. found that the similar effect of temperature on reducing power of soybean hydrolysates [36]. Guerard et al. have also reported during the hydrolysis of shrimp processing discards, temperature and $\mathrm{pH}$ played the similar impact on antiradical activity [31]. There were several reasons for these changes in inhibitory rate: firstly, the temperature in our study covered with the range of $35-45^{\circ} \mathrm{C}$, some proteins in the hydrolysates might be denatured at their denaturation temperature. Meanwhile, the activity of alkaline protease might be decreased. At lower temperatures, the rate of enzyme heat-inactivation was slower in comparison with the rate of the enzyme catalyzed reaction. At higher temperatures, the increased heat-inactivation rate led to a faster decrease in the number of active catalyst molecules [37]. In addition, high temperature also increased the cost of the hydrolysis process.

The variation of the PPL inhibitory rate with changing initial $\mathrm{pH}$ and hydrolysis time were presented in Figure 2b. Initial pH showed a quadratic effect on the response, hence the PPL inhibitory rate firstly increased and then decreased with initial $\mathrm{pH}$ increasing. The report by Cao et al. [38] also 
showed the similar effect of $\mathrm{pH}$ on autolysis processing of shrimp head. The solubility of protein was affected by $\mathrm{pH}$ value, because of the isoelectric point of each protein. In addition, the $\mathrm{pH}$ of the hydrolysis condition decreased with the reaction time. In order to keep the $\mathrm{pH}$ at optimal condition as long as possible, without influencing the activity of protease, it was suggested that, when the initial $\mathrm{pH}$ was given at about 11 , alkaline protease exhibited the highest activity.

Figure 2. Response surface plots and contour plots for the interactive effects of variables on the porcine pancreas lipase (PPL) inhibitory rate. (a) the interactive effects of initial $\mathrm{pH}$ and temperature, maintaining fixed enzyme dosage $100 \mathrm{U} / \mathrm{mL}$, hydrolysis time $10 \mathrm{~h}$; (b) the interactive effects of initial $\mathrm{pH}$ and hydrolysis time, maintaining fixed enzyme dosage $100 \mathrm{U} / \mathrm{mL}$, temperature $45{ }^{\circ} \mathrm{C}$; (c) the interactive effects of temperature and hydrolysis time, maintaining fixed enzyme dosage $100 \mathrm{U} / \mathrm{mL}$, initial $\mathrm{pH} \mathrm{11}$; (d) the interactive effects of enzyme dosage and hydrolysis time, maintaining fixed initial $\mathrm{pH} 11$, temperature $45^{\circ} \mathrm{C}$.

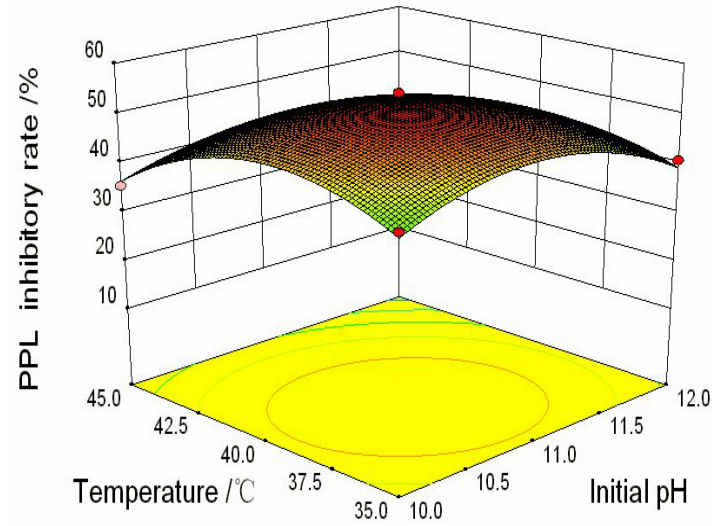

(a)

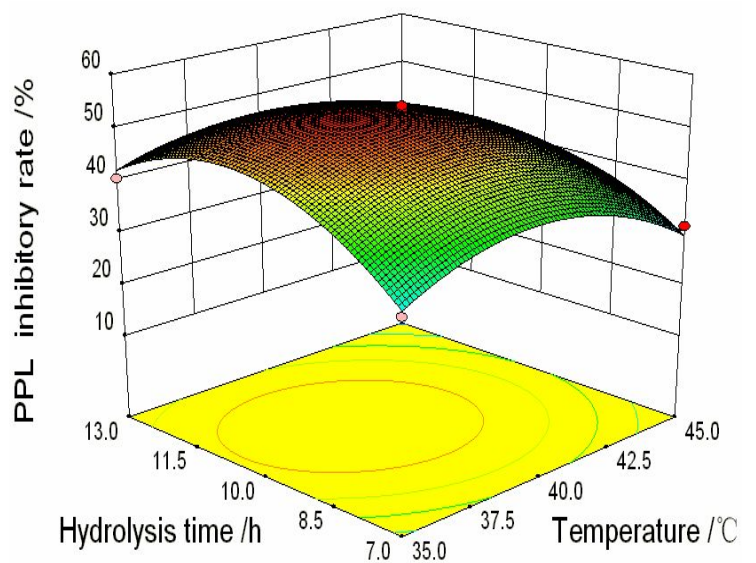

(c)

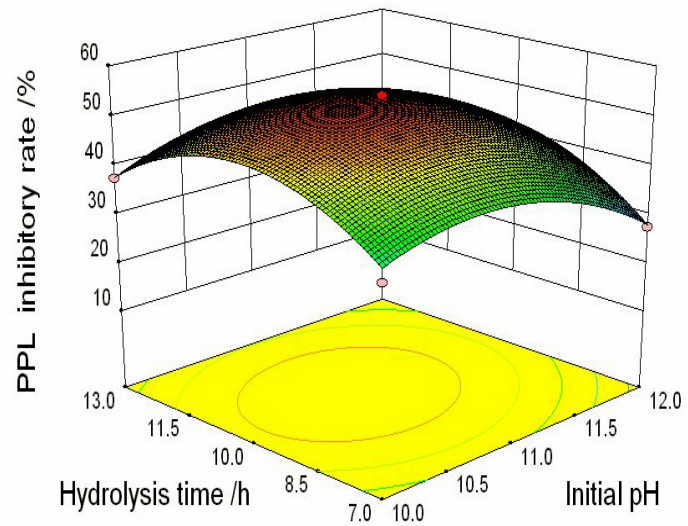

(b)

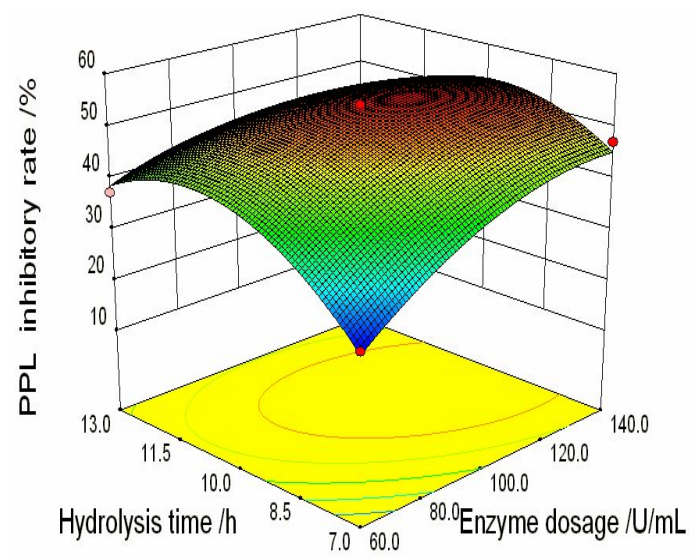

(d)

It was clear from Figure $2 \mathrm{c}$ that at the designed range of temperature from 35 to $45{ }^{\circ} \mathrm{C}$, the PPL inhibitory rate increased quickly at the start and then decreased slowly with the time increasing. Reaction time had a positive linear effect on the inhibitory rate. However, further an increase in reaction time resulted in a little decrease in the inhibitory rate. It was in accordance with the previous study by Song et al. [39], which reported the hydrolysis time influenced the antibacterial activity of Half-Fin Anchovy (Setipinna taty) hydrolysates in a liner manner at lower levels of $\mathrm{pH}$, while at upper 
levels of $\mathrm{pH}$, the influence was quadratic. This phenomenon could be probably explained as: The degradation of fish water-soluble protein was mainly a chemical process achieved by hydrolysis of peptide bond. The number of hydrolyzed peptide bonds increased with the extension of the reaction time, and the inhibitory rate increased. While the reaction time was further extended, the decrease in the inhibitory rate became due to the further hydrolysis of the functional polypeptides, and the polypeptides activity declined.

Figure $2 \mathrm{~d}$ illustrated the effects of the enzyme dosage and the hydrolysis time on the PPL inhibitory rate while maintaining the temperature at $40{ }^{\circ} \mathrm{C}$ and the initial $\mathrm{pH}$ at 11 . It can be found that the enzyme dosage had a significant positive linear effect on the PPL inhibitory rate when the enzyme dosage was lower than $100 \mathrm{U} / \mathrm{mL}$. For a dosage over this critical value, little enhancements in the PPL inhibitory rate attributable to the increase of enzyme dosage were observed, which could be explained by the fact that the enzyme had saturated the hydrolysates. Song et al. [39] have also reported the similar effect of enzyme dosage on the antibacterial activity of Half-Fin Anchovy (Setipinna taty) hydrolysates.

The effects of variables on $\alpha$-amylase inhibitory activity were similar to those on pancreatic lipase inhibitory activity. It can be concluded from Table 1, considering the interactive effects of variables on the $\alpha$-amylase inhibitory rate, that $\chi_{1} \chi_{2}, \chi_{1} \chi_{4}, \chi_{2} \chi_{4}$ were significant model terms, while $\chi_{1} \chi_{3}, \chi_{2} \chi_{3}, \chi_{3} \chi_{4}$ were not significant model terms. Figure 3 exhibited the interactive effects of temperature $\left(\chi_{2}\right)$ and hydrolysis time $\left(\chi_{4}\right)$ on the $\alpha$-amylase inhibitory rate, as well as the effects of initial $\mathrm{pH}\left(\chi_{1}\right)$ and enzyme dosage $\left(\chi_{3}\right)$. 2D contour plots showed the interrelationships between two tested variables and the relationship between responses and experimental levels of each variable. Different shapes of contour plots indicated different interactions between two variables. A full elliptic contour was observed in Figure 3a, indicating a significant interaction between temperature and hydrolysis time. In the contrast, circular contour plot, which signaled non-significance for the interactions between initial $\mathrm{pH}$ and enzyme dosage, was clearly shown in Figure $3 \mathrm{~b}$.

Figure 3. Contour plots for the interactive effects of variables on the $\alpha$-amylase inhibitory rate. (a) the interactive effects of hydrolysis time and temperature, maintaining fixed enzyme dosage $100 \mathrm{U} / \mathrm{mL}$, initial $\mathrm{pH} \mathrm{11;} \mathrm{(b)} \mathrm{the} \mathrm{interactive} \mathrm{effects} \mathrm{of} \mathrm{enzyme} \mathrm{dosage} \mathrm{and}$ initial $\mathrm{pH}$, maintaining fixed hydrolysis time $10 \mathrm{~h}$, temperature $45^{\circ} \mathrm{C}$.

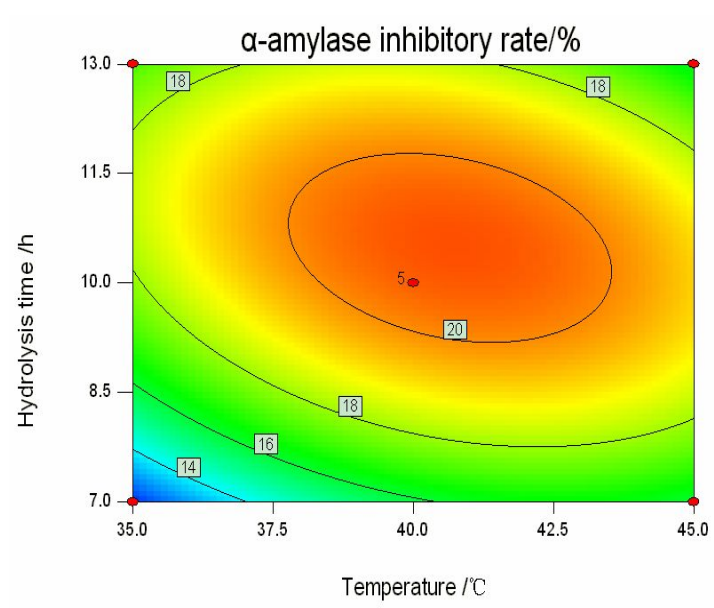

(a)

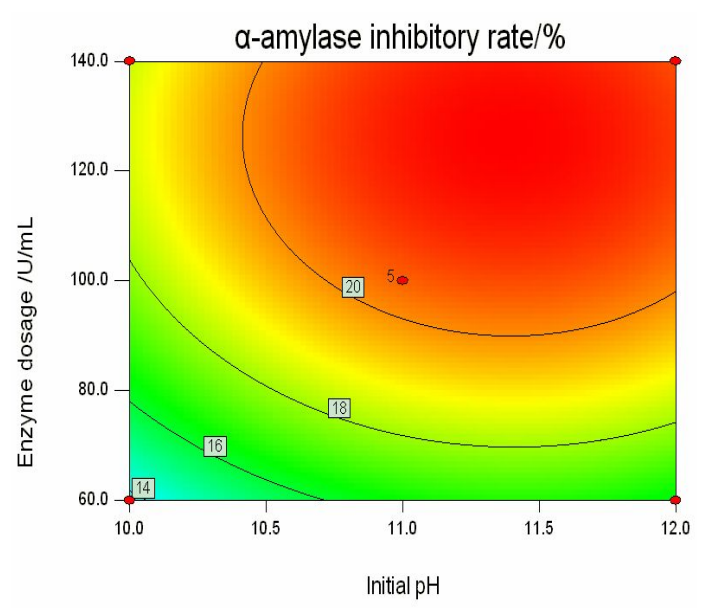

(b) 


\subsection{Optimization of the Hydrolysis Conditions and Validation of Model}

The optimum values were found by solving the regression equation analytically. The optimal hydrolysis reaction conditions were calculated as follows: initial $\mathrm{pH} 11.08$, temperature $39.50{ }^{\circ} \mathrm{C}$, enzyme dosage $121.76 \mathrm{U} / \mathrm{mL}$ and hydrolysis time $10.21 \mathrm{~h}$. Considering the cost and the operating convenience of the hydrolysis process, the optimal values of variables were determined as follows: initial $\mathrm{pH} 11$, temperature $39{ }^{\circ} \mathrm{C}$, enzyme dosage $122 \mathrm{U} / \mathrm{mL}$ and time $10 \mathrm{~h}$. To validate the predicted model, the tests were carried out at optimal conditions for $\mathrm{pH}$, temperature, enzyme dosage, and hydrolysis time in triplicate. The predicted response $\mathrm{Y}_{1}(54.63 \% \pm 1.75 \%)$ and $\mathrm{Y}_{2}(21.22 \% \pm 0.70 \%)$ were experimentally verified $(53.04 \% \pm 1.32 \%, 20.03 \% \pm 0.89 \%, n=3)$.

The adequacy of the response surface equations was indicated by a comparison between the experimental value and the predicted data. The comparison was done by generating a fitted-line plot for the results obtained, showing how close it was to or how far it deviated from the fitted line. As shown in Figure 4a,b, the agreement between predicted values and experimental values confirmed that the response surface models were adequate for predicting the varied enzymatic properties as functions of the conditions.

Figure 4. Fitted line plot indicating the closeness between predicted values and experimental values for porcine pancreas lipase (PPL) inhibitory rate (a) and $\alpha$-amylase inhibitory rate $(\mathbf{b})$.

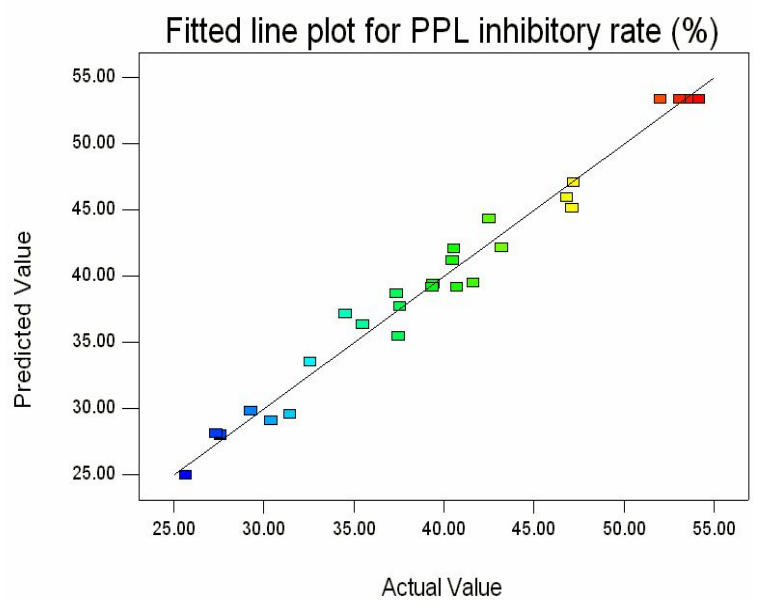

(a)

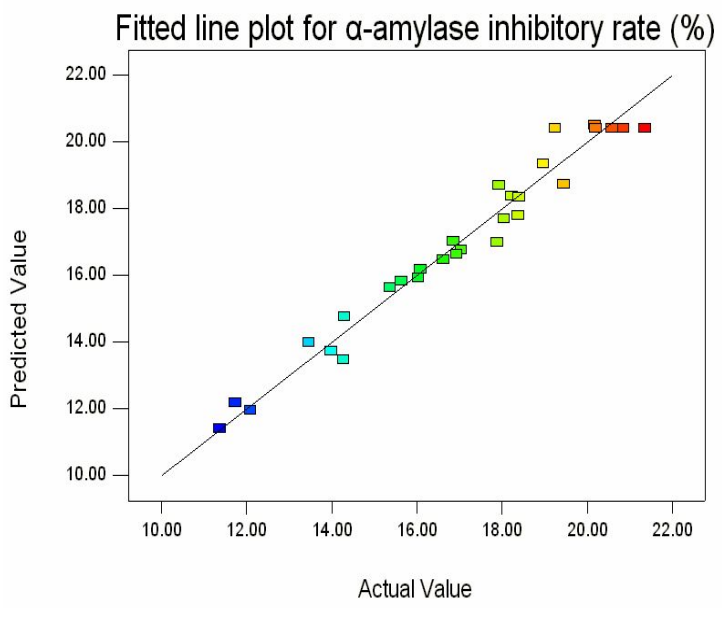

(b)

\subsection{Manner of Inhibition by FPH}

The inhibitory mechanism of FPH was shown in Figure 5. In order to clarify the kinetics of inhibition against PPL by FPH, the inhibitory type was determined by Lineweaver-Burk plots, and kinetic parameters $\left(V_{\max }, K_{\mathrm{m}}\right.$ and $\left.K_{\mathrm{i}}\right)$ were calculated by Michealis equation. The inhibitory activity was measured by changing the concentration of the substrate at a constant concentration $[0 \mathrm{mg} / \mathrm{mL}(\bullet)$, $60 \mathrm{mg} / \mathrm{mL}(\boldsymbol{\square})$ and $90 \mathrm{mg} / \mathrm{mL}(\boldsymbol{\Delta})]$ of polypeptide in hydrolysates. Because the plots obtained by changing the substrate concentration intersected with the $\chi$ axis, it was indicated that the mechanism of PPL inhibition by FPH was noncompetitive type, which meant that FPH could combine with an enzyme molecule to produce a dead-end complex, regardless of whether a substrate molecule was 
bound or not. Hence, FPH must bind at a different site from the substrate. Therefore, FPH acted as a PPL inhibitor by forming enzyme-substrate-inhibitor and enzyme-inhibitor complexes to reduce the efficiency of catalysis during the reaction. The similar results were also observed by Li et al. [40], which reported the mechanism of pancreatic lipase inhibition by flavonoids was noncompetitive. On the basis of linear regression analysis of Lineweaver-Burk plots and Michealis equation, $V_{\max }, K_{\mathrm{m}}$ and $K_{\mathrm{i}}$ were calculated to be $1.237 \%, 0.0512 \mathrm{mg} / \mathrm{mL}$ and $84.13 \mathrm{mg} / \mathrm{mL}$, respectively.

Figure 5. Lineweaver-Burk plots for the inhibition of porcine pancreas lipase (PPL) by fish protein hydrolysates (FPH). The reactions were performed at a constant concentration $[0 \mathrm{mg} / \mathrm{mL}(\bullet), 60 \mathrm{mg} / \mathrm{mL}(\boldsymbol{\bullet})$ and $90 \mathrm{mg} / \mathrm{mL}(\boldsymbol{\Delta})]$ of polypeptide in hydrolysates. Each bar showed the standard deviations. Values were the means of triplicate analyses.

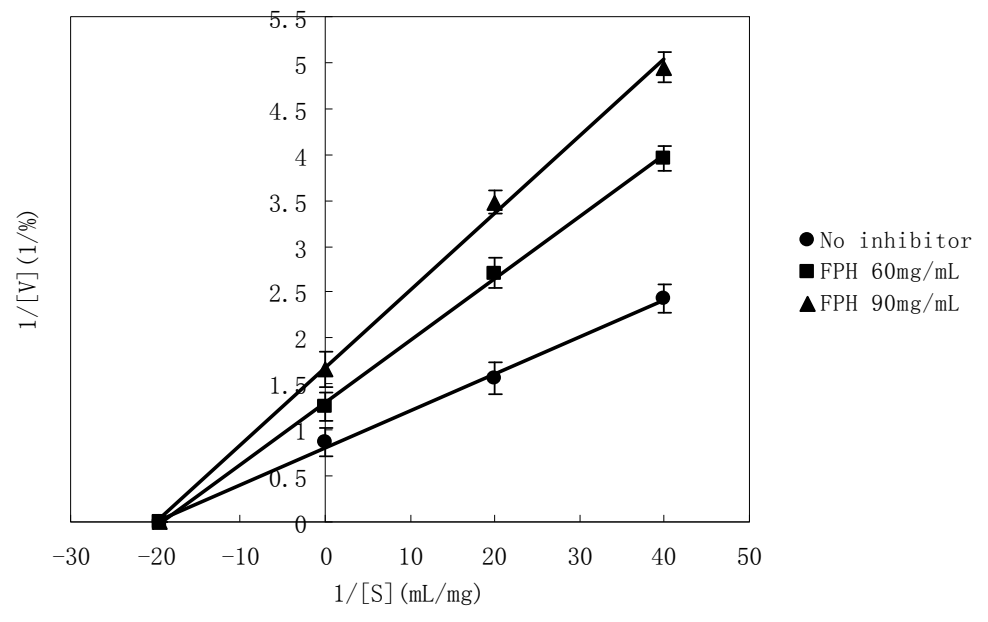

\section{Experimental Section}

\subsection{Materials and Methods}

\subsubsection{Materials}

Chemicals and enzymes used for this study were listed along with their sources as follows: porcine pancreas lipase (30 U/mg, Glycerol trioleate was used as substrate) was purchased from Jianglai Bioengineering Co. Ltd (Shanghai, China); alkaline protease $(200 \mathrm{U} / \mathrm{mg}$, Casein was used as substrate), neutral protease (200 U/mg, Casein was used as substrate), papain (100 U/mg, Casein was used as substrate), and protamex (300 U/mg, Casein was used as substrate) from Noao Bioengineering Co. Ltd (Tianjin, China); crucian carp (Carassius carassius) was purchased from market (Tianjin, China). All other chemicals were of reagent grade.

\subsubsection{Pretreatment and Enzymatic Hydrolysis}

Fish muscle from crucian carp (Carassius carassius) was ground to uniformity with a homogenizer after removal of head and viscera. Based on the preliminary experiment, deionized water was added at a water/fish muscle ratio of 10:1 $(v / w)$ in a conical flask $(250 \mathrm{~mL})$. After stirred at $150 \mathrm{rmp}$ for $3 \mathrm{~h}$ at $43{ }^{\circ} \mathrm{C}$, the mixture was then cooled and centrifuged at $2000 \times \mathrm{g}$ for $15 \mathrm{~min}$, to collect the supernatant. 
Fish water-soluble protein in the supernatant was measured by the Biuret method according to Layne (1957) using bovine serum albumin as the standard.

The supernatant was adjusted to a suitable $\mathrm{pH}$ with $2.0 \mathrm{M} \mathrm{HCl}$ or $2.0 \mathrm{M} \mathrm{NaOH}$, then separately digested by neutral protease, alkaline protease, papain, and protamex $(100 \mathrm{U} / \mathrm{mL})$ for $14 \mathrm{~h}$. The hydrolysis temperature was controlled at $45{ }^{\circ} \mathrm{C}$ for neutral protease and alkaline protease, $55{ }^{\circ} \mathrm{C}$ for papain and protamex. The hydrolysis initial $\mathrm{pH}$ was 7.0 for neutral protease, protamex and papain, 10.0 for alkaline protease. The reaction was stopped by boiling for $15 \mathrm{~min}$. Then the supernatant was used for determination of the PPL and the $\alpha$-amylase inhibitory activities. The optimal protease was chosen according to the DH and the PPL inhibitory rate.

\subsubsection{Assay for PPL Inhibitory Activity}

The ability of the compounds to inhibit PPL was measured using the method previously reported by Kim et al. [41], with some modifications.

Lipase activity was determined by measuring the fatty acid released from olive oil. Briefly, a mixture of olive oil and polyvinyl alcohol $(1: 3, v / v)$ was used as the substrate. Firstly $2.0 \mathrm{~mL}$ of the substrate and $2.5 \mathrm{~mL}$ of phosphate buffer $(0.05 \mathrm{M}, \mathrm{pH} 7.0)$ were pre-incubated for $5 \mathrm{~min}$ at $40{ }^{\circ} \mathrm{C}$, then $0.5 \mathrm{~mL}$ of sample and $0.5 \mathrm{~mL}$ of porcine pancreatic lipase solution were added and the enzymatic reactions were allowed to proceed for $15 \mathrm{~min}$ at $40{ }^{\circ} \mathrm{C}$. After incubation, the reaction mixture was stopped by adding $6.0 \mathrm{~mL}$ of alcohol and $1.0 \mathrm{~mL}$ of $\mathrm{HCl}$. Then, $3.0 \mathrm{~mL}$ of isooctane was added to extract fatty acid released by olive oil from the reaction mixture. After strongly vortexing for $90 \mathrm{~s}$, $1.0 \mathrm{~mL}$ of isooctane layer was taken out and dissolved in $4.0 \mathrm{~mL}$ of isooctane and $1.0 \mathrm{~mL}$ of copper aeetate monohydrate. Then after strongly vortexing for $90 \mathrm{~s}$, the supernatant was obtained and measured for the inhibition of the lipase activity. Triplicate tests were performed for each sample.

The lipase activity was determined by OD value at $714 \mathrm{~nm}$. Inhibition of the lipase activity was expressed as the percentage decrease in the OD value when PPL was incubated with the test compounds. Lipase inhibitory rate was calculated as follows:

$$
\text { Lipase inhibitory rate }(\%)=\left(1-A_{\mathrm{b}} / A_{\mathrm{a}}\right) \times 100
$$

where $A_{\mathrm{a}}$ represented the lipase activity without any inhibitor, $A_{\mathrm{b}}$ represented the lipase activity in the presence of hydrolysates.

\subsubsection{Assay for $\alpha$-Amylase Inhibitory Activity}

The inhibition assay was performed using the chromogenic DNSA (3,5-dinitrosalicylicacid) method [42]. The total assay mixture composed of $1.0 \mathrm{~mL}$ of salivary $\alpha$-amylase solution and $1.0 \mathrm{~mL}$ of sample were incubated at $37^{\circ} \mathrm{C}$ for $15 \mathrm{~min}$. After pre-incubation, $1.0 \mathrm{~mL}$ of $2 \%(v / v)$ starch solution was added and incubated at $37^{\circ} \mathrm{C}$ for 5 min accurately. The reaction was terminated with $2.0 \mathrm{~mL}$ DNSA reagent, placed in boiling water bath for $5 \mathrm{~min}$, cooled to room temperature, diluted and the absorbance was measured at $540 \mathrm{~nm}$. $\alpha$-Amylase inhibitory rate was calculated as follows:

$$
\alpha \text {-amylase inhibitory rate }(\%)=\left(1-A_{\mathrm{b}} / A_{\mathrm{a}}\right) \times 100
$$

where $A_{\mathrm{a}}$ represented the $\alpha$-amylase activity without any inhibitor, $A_{\mathrm{b}}$ represented the $\alpha$-amylase activity in the presence of hydrolysates. 


\subsubsection{Assay for Degree of Hydrolysis}

Degree of hydrolysis (DH) was defined as the percentage of free amino groups cleaved from protein, which was calculated from ratio of $\alpha$-amino nitrogen (AN) and total nitrogen (TN). The AN was determined by a modified formol titration method [43]. Ten milliliter of FPH was added with an equal amount of distilled water. The mixture was adjusted to $\mathrm{pH} 7.0$ using $0.1 \mathrm{M} \mathrm{NaOH}$. Then $10.0 \mathrm{~mL}$ of $38 \%(v / v)$ formaldehyde solution was added into the mixture and titration was continued to the end point at $\mathrm{pH} 9.5$ with $0.2 \mathrm{M}$ standard $\mathrm{NaOH}$ solutions. TN was determined by Kjeldahl method [44].

\subsubsection{Experimental Design and Statistical Analysis}

For the enzymatic reaction, many factors could affect the enzymatic hydrolysis efficiency significantly, such as enzyme specificity, $\mathrm{pH}$, temperature, enzyme dosage, substrate concentration and hydrolysis time [45-48]. The initial assays were based on one-factor design with some different initial $\mathrm{pH}$ values, as well as temperatures, enzyme dosages and hydrolysis time. The composition of the model was established from these preliminary assays. The optimal values of the selected variables were obtained by regression analysis on Design-Expert 7.0 (Stat-Ease Inc.: Minneapolis, MN, USA). A four-factor-three-level Box-Behnken design (BBD) was employed in this study, and all 29 of the designed experiments were conducted and performed in triplicate to optimize the four independent variables.

Four main factors namely initial $\mathrm{pH}\left(X_{1}\right)$, temperature $\left(X_{2}\right)$, enzyme dosage $\left(X_{3}\right)$, and hydrolysis time $\left(X_{4}\right)$ were chosen as the independent variables. The range and center point values of four independent variables were shown in Table 3. The coded $(\chi)$ and actual $(X)$ levels of variables in the experimental design were shown in Table 3.

Table 3. Independent variables and their levels used in the RSM experimental design.

\begin{tabular}{cccc}
\hline \multirow{2}{*}{ Variables } & \multicolumn{3}{c}{ Coded level } \\
\cline { 2 - 4 } & $\mathbf{- 1}$ & $\mathbf{0}$ & $\mathbf{+ 1}$ \\
\hline Initial $\mathrm{pH}\left(X_{1}\right)$ & 10 & 11 & 12 \\
Temperature $\left(X_{2}\right),{ }^{\circ} \mathrm{C}$ & 35 & 40 & 45 \\
Enzyme dosage $\left(X_{3}\right), \mathrm{U} / \mathrm{mL}$ & 60 & 100 & 140 \\
Hydrolysis time $\left(X_{4}\right), \mathrm{h}$ & 7 & 10 & 13 \\
\hline$\chi_{1}=\left(X_{1}-11\right) / 1 ; \chi_{2}=\left(X_{2}-40\right) / 5 ; \chi_{3}=\left(X_{3}-100\right) / 40 ; \chi_{4}=\left(X_{4}-10\right) / 3$.
\end{tabular}

The responses $(Y)$ were the PPL inhibitory rate and the $\alpha$-amylase inhibitory rate. The quadratic model for predicting the optimal point was expressed according to the Equation 5:

$$
Y=\mathrm{b}_{0}+\sum \mathrm{b}_{i} \chi_{i}+\sum \mathrm{b}_{i i} \chi_{i}^{2}+\sum \mathrm{b}_{i j} \chi_{i} \chi_{j}
$$

where $Y$ were the response variables, $\mathrm{b}_{0}, \mathrm{~b}_{i}, \mathrm{~b}_{i i}, \mathrm{~b}_{i j}$ were the regression coefficient variables, for intercept, linear, quadratic and interaction regression terms, respectively, and $\chi_{i}$ and $\chi_{j}$ were independent variables. 


\section{Conclusions}

The hydrolysis condition of fish water-soluble protein by alkaline protease was optimized by using RSM as follows: initial $\mathrm{pH} 11$, temperature $39^{\circ} \mathrm{C}$, enzyme dosage $122 \mathrm{U} / \mathrm{mL}$ and hydrolysis time $10 \mathrm{~h}$. To validate the predicted model, the tests were carried out at optimal conditions in triplicate. The PPL and the $\alpha$-amylase inhibitory rate after optimization could reach $53.21 \% \pm 1.07 \%, 20.07 \% \pm 0.87 \%$ respectively, while predicted values were $54.63 \% \pm 1.75 \%, 21.22 \% \pm 0.70 \%$ respectively. In addition, the manner of PPL inhibition by FPH was analyzed, and the Lineweaver-Burk plots showed noncompetitive inhibition. The $K_{\mathrm{i}}$ value calculated from the data in Figure 5 was $84.13 \mathrm{mg} / \mathrm{mL}$.

\section{References}

1. Hill, J.O.; Melanson, E.L.; Wyatt, H.T. Dietary fat intake and regulation of energy balance: Implications for obesity. J. Nutr. 2000, 130, 284S-288S.

2. Leslie, W.S.; Lean, M.E.J.; Baillie, H.M.; Hankey, C.R. Weight management: A comparison of existing dietary approaches in a work-site setting. Int. J. Obesity 2002, 26, 1469-1475.

3. Leonhardt, M.; Hrupka, B.; Langhans, W. New approaches in the pharmacological treatment of obesity. Eur. J. Nutr. 1999, 38, 1-13.

4. Gargouri, Y.; Ransac, S.; Verger, R. Covalent inhibition of digestive lipases: An in vitro study. Biochim. Biophysica. Acta 1997, 1344, 6-37.

5. McNeely, W.; Goa, K.L. Sibutramine: A review of its contribution to the management of obesity. Drugs 1998, 56, 1093-1124.

6. Lee, S.H.; Park, M.H.; Heo, S.J.; Kang, S.M.; Ko, S.C.; Han, J.S.; Jeon, Y.J. Dieckol isolated from Ecklonia cava inhibits alpha-glucosidase and alpha-amylase in vitro and alleviates postprandial hyperglycemia in streptozotocin-induced diabetic mice. Food Chem. Toxicol. 2010, 48, 2633-2637.

7. Akkarachiyasit, S.; Charoenlertkul, P.; Yibchok-Anun, S.; Adisakwattana, S. Inhibitory activities of cyanidin and its glycosides and synergistic effect with acarbose against intestinal $\alpha$-glucosidase and pancreatic $\alpha$-amylase. Int. J. Mol. Sci. 2010, 11, 3387-3396.

8. Baron, A.D. Postprandial hyperglycaemia and alpha-glucosidase inhibitors. Diabetes Res. Clin. Pract. 1998, 40, S51-S55.

9. Tsujita, T.; Matsuura, Y.; Okuda, H. Studies on the inhibition of pancreatic and carboxylester lipases by protamine. J. Lipid Res. 1996, 37, 1481-1487.

10. Borel, P.; Lairon, D.; Termine, E.; Grataroli, R.; Lafont, H. Isolation and properties of lipolysis inhibitory proteins from wheat germ and wheat bran. Plant Foods Hum. Nutr. 1989, 39, 339-348.

11. Tani, H.; Ohishi, H.; Watanabe, K. Purification and characterization of proteinous inhibitor of lipase from wheat flour. J. Agric. Food Chem. 1994, 42, 2382-2385.

12. Satouchi, K.; Mori, T.; Matsushita, S. Characterization of inhibitor protein for lipase in soybean seeds. Agric. Biol. Chem. 1974, 38, 97-101. 
13. Sirtori, C.R.; Lovati, M.R.; Manzoni, C.; Castiglioni, S.; Duranti, M.; Magni, C.; Morandi, S.; D'Agostina, A.; Arnoldi, A. Proteins of white lupin seed, a naturally isoflavone-poor legume, reduce cholesterolemia in rats and increase LDL receptor activity in HepG2 cells. J. Nutr. 2004, $134,18-23$.

14. Tsutsumi, K.; Kawauchi, Y.; Kondo, Y.; Inoue, Y.; Koshitani, O.; Kohri, H. Water extract of defatted rice bran suppresses visceral fat accumulation in rats. J. Agric. Food Chem. 2000, 48, 1653-1656.

15. Niiho, Y.; Yamazaki, T.; Hosono, T.; Nakajima, Y.; Ishizaki, M.; Kurashige, T. Pharmacological studies on small peptide fraction derived soybean. Yakugaku Zasshi 1993, 113, 334-342.

16. Hyun, J.K.; In, Y.B.; Chang-Won, A.; Suyong, L.; Hyeon, G.L. Purification and identification of adipogenesis inhibitory peptide from black soybean protein hydrolysate. Peptides 2007, 28, 2098-2103.

17. Rho, S.J.; Park, S.; Ahn, C.W.; Shin, J.K.; Lee, H.G. Dietetic and hypocholesterolaemic action of black soy peptide in dietary obese rats. J. Sci. Food Agric. 2007, 87, 908-913.

18. Kagawa, K.; Matsutaka, H.; Fukuhama, C.; Watanabe, Y.; Fujino, H. Globin digest, acidic protease hydrolysate, inhibits dietary hypertriglyceridemia and Val-Val-Tyr-Pro, one of its constituents, possesses most superior effect. Life Sci. 1996, 58, 1745-1755.

19. Wergedahl, H.; Liaset, B.; Gudbrandsen, O.A.; Lied, E.; Espe, M.; Muna, Z.; Mork, S.; Berge, R.K. Fish protein hydrolysate reduces plasma total cholesterol, increases the proportion of HDL cholesterol, and lowers acyl-CoA: Cholesterol acyltransferase activity in liver of Zucker rats. J. Nutr. 2004, 134, 1320-1327.

20. Je, J.Y.; Park, P.J.; Kwon, J.Y.; Kim, S.K. A novel Angiotensin I converting enzyme inhibitory peptide from Alaska Pollack (Theragra chalcogramma) frame protein hydrolysate. J. Agric. Food Chem. 2004, 52, 7842-7845.

21. Je, J.Y.; Park, P.J.; Kim, S.K. Antioxidant activity of a peptide isolated from Alaska pollack (Theragra chalcogramma) frame protein hydrolysate. Food Res. Int. 2005, 38, 45-50.

22. Sampath Kumar, N.S.; Nazeer, R.A.; Jaiganesh, R. Purification and identification of antioxidant peptides from the skin protein hydrolysate of two marine fishes, horse mackerel (Magalaspis cordyla) and croaker (Otolithes ruber). Amino Acids 2012, 42, 1641-1649.

23. Klompong, V.; Benjakul, S.; Kantachote, D.; Shahidi, F. Antioxidative activity and functional properties of protein hydrolysate of yellow stripe trevally (Selaroides leptolepis) as influenced by the degree of hydrolysis and enzyme type. Food Chem. 2007, 102, 1317-1327.

24. Chabeaud, A.; Dutournié, P.; Guérard, F.; Vandanjon, L.; Bourseau, P. Application of response surface methodology to optimise the antioxidant activity of a Saithe (Pollachius virens) hydrolysate. Mar. Biotechnol. 2009, 11, 445-455.

25. Duartea, J.; Vinderola, G.; Ritzc, B.; Perdigón, G.; Matar, C. Immunomodulating capacity of commercial fish protein hydrolysate for diet supplementation. Immunobiology 2006, 211, 341-350.

26. Murraya, A.L.; Pascho, R.J.; Alcornb, S.W.; Fairgrievec, W.T; Shearerc, K.D; Roley, D. Effects of various feed supplements containing fish protein hydrolysate or fish processing by-products on the innate immune functions of juvenile coho salmon (Oncorhynchus kisutch). Aquaculture 2003, 220, 643-653.

27. Nilsang, S.; Lertsiri, S.; Suphantharika, M.; Assavanig, A. Optimization of enzymatic hydrolysis of fish soluble concentrate by commercial proteases. J. Food Eng. 2005, 70, 571-578. 
28. Gbogouri, G.A.; Linder, M.; Fanni, J.; Parmentier, M. Influence of hydrolysis degree on the functional properties of salmon byproducts hydrolysates. J. Food Sci. 2004, 69, 615-622.

29. Bhaskar, N.; Benila, T.; Radha, C.; Lalitha, R.G. Optimization of enzymatic hydrolysis of visceral waste proteins of Catla (Catla catla) for preparing protein hydrolysate using a commercial protease. Bioresour. Technol. 2008, 99, 335-343.

30. Ovissipour, M.; Kenari, A.A.; Motamedzadegan, A.; Nazari, R.M. Optimization of enzymatic hydrolysis of visceral waste proteins of yellowfin tuna (Thunnus albacares). Food Bioprocess Technol. 2012, 5, 696-705.

31. Guerard, F.; Sumaya-Martinez, M.T.; Laroque, D.; Chabeaud, A.; Dufossé, L. Optimization of free radical scavenging activity by response surface methodology in the hydrolysis of shrimp processing discards. Process Biochem. 2007, 42, 1486-1491.

32. Dufossé, L.; De La Broise, D.; Guérard, F. Fish protein hydrolysates as nitrogen sources for microbial growth and metabolite production. Recent Res. Dev. Microbiol. 1997, 1, 365-381.

33. Normah I.; Jamilah, B. Optimization of hydrolysis conditions for the production of thread finbream ( Nemipterus japonicus) hydrolysate by Alcalase. J. Muscle Food. 2005, 16, 87-102.

34. Ren, J.Y.; Zhao, M.M.; Shi, J.; Wang, J.S.; Jiang, Y.M.; Cui, C.; Kakuda, Y.; Xue, S.J. Optimization of anti-oxidant peptide production from grass carp sarcoplasmic protein using response surface methodology. Food Sci. Technol. 2008, 41, 1624-1632.

35. Zhuang, Y.L.; Zhao, X.; Li, B.F. Optimization of antioxidant activity by response surface methodology in hydrolysates of jellyfish (Rhopilema esculentum) umbrella collagen. J. Zhejiang Univ.-Sci. B 2009, 10, 572-579.

36. Hou, L.X.; Wang, J.S.; Zhang, D. Optimization of debittering of soybean antioxidant hydrolysates with $\beta$-cyclodextrins using response surface methodology. J. Food Sci. Technol. 2011, doi:10.1007/s13197-011-0358-4.

37. Habulin, M.; Knez, Z. High-pressure enzymatic hydrolysis of oil. Eur. J. Lipid Sci. Technol. 2002, 104, 381-386.

38. Cao, W.H.; Zhang, C.H.; Hong, P.Z.; Ji, H.W. Response surface methodology for autolysis parameters optimization of shrimp head and amino acids released during autolysis. Food Chem. 2008, 109, 176-183.

39. Song, R.; Wei, R.B.; Zhang, B.; Wang, D.F. Optimization of the antibacterial activity of Half-Fin Anchovy (Setipinna taty) Hydrolysates. Food Bioprocess Technol. 2012, 5, 1979-1989.

40. Li, Y.Q.; Yang, P.; Gao, F.; Zhang, Z.W.; Wu, B. Probing the interaction between 3 flavonoids and pancreatic lipase by methods of fluorescence spectroscopy and enzymatic kinetics. Eur. Food Res. Technol. 2011, 233, 63-69.

41. Kim, J.H.; Kim, H.J.; Park, H.W.; Youn, S.H.; Choi, D.Y.; Shin, C.S. Development of inhibitors against lipase and alpha-glucosidase from derivatives of monascus pigment. FEMS Microbiol. Lett. 2007, 276, 93-98.

42. Miller, G.L. Use of dinitrosalicylic acid reagent for determination of reducing sugar. Anal. Chem. 1959, 3, 426-428.

43. The United States Pharmacopeial Convention. United States Pharmacopea, 22nd ed.; Rockville, MD, USA, 1989. 
44. Association of Official Analytical Chemists. Official Methods of Analysis, 15th ed.; Washington, DC, USA, 1990.

45. Yemul, O.; Imae, T. Covalent-bonded immobilization of lipase on poly(phenylene sulfide) dendrimers and their hydrolysis ability. Biomacromolecules 2005, 6, 2809-2814.

46. Yadav, G.D.; Devi, K.M. Kinetics of hydrolysis of tetrahydrofurfuryl butyrate in a three phase system containing immobilized lipase from Candida Antarctica. Biochem. Eng. J. 2003, 17, 57-63.

47. Kaambre, T.; Tougu, V.; Kaambre, P.; Vija, H.; Sikk, P. Hydrolysis of emulsified mixtures of triacylglycerols by pancreatic lipase. Biochim. Biophys. Acta 1999, 1431, 97-106.

48. Linfield, W.M.; Barauskas, R.A.; Sivieri, L.; Serota, S.; Stevenson, R.W. Enzymatic fat hydrolysis and synthesis. J. Am. Oil Chem. Soc. 1984, 61, 191-195.

(C) 2013 by the authors; licensee MDPI, Basel, Switzerland. This article is an open access article distributed under the terms and conditions of the Creative Commons Attribution license (http://creativecommons.org/licenses/by/3.0/). 